\title{
Investigating the Transmission Channels of the Global Financial Crisis to Tanzania
}

\author{
Maduhu Kazi \\ Department of Economics Bank of Tanzania, Zanzibar, United Republic of Tanzania \\ Email: maduhuk@yahoo.com
}

Received 31 January 2014; revised 2 March 2014; accepted 9 March 2014

Copyright (C) 2014 by author and Scientific Research Publishing Inc.

This work is licensed under the Creative Commons Attribution International License (CC BY). http://creativecommons.org/licenses/by/4.0/

(c) (7) Open Access

\begin{abstract}
This paper uses a series of Tanzania's annual real GDP data for the period of 1970 to 2010, to investigate the transmission channels through which the ongoing financial crisis is affecting the economy. The channels which were examined are foreign aid, export earnings and Foreign Direct Investment (FDI). The paper also investigated how an increase in government expenditure, as popularly known as the stimulus package can boost the Tanzanian economy. Foreign aid was found to possess the positive sign as was expected and is statistically significant. Therefore there is a possibility that the ongoing global crisis has impacted the economy via a reduced foreign aid which is associated with recession in the developed economies; aid donors in this context. It was also found that the global financial crisis had a significant effect on Tanzania's economic growth through other transmission channels namely FDI and exports. However, all the coefficients were small, indicating the little impact of the global financial crisis to Tanzania's economy.
\end{abstract}

\section{Keywords}

Tanzania, Transmission Channels, Global Financial Crisis

\section{Introduction}

Recently, the world witnessed a severe global wide financial crisis beginning in mid-2007 (IMF, [1] [2]). As with major international crises such as those of the 1990's in emerging and relatively developed countries such as the 1994 Mexico peso crisis, the 1997 East Asian crisis, the 1998 Russian financial crisis and the 1999 Brazilian real devaluation, most crises have a common characteristic that they tend to have profound effects on other countries. From this point of view I observe that financial crises portray a contagious characteristic because they tend to spread quickly in their effects from the initial epicenters (AfDB, [3] and Wakeman et al., [4]).

The recent global financial crisis, which originated from the subprime mortgage lending problems in the 
United States, led to major negative effects on global economic performance, trade, private capital flows and employment; among others ${ }^{1}$. This crisis is claimed to be different from earlier ones for several factors. For example it originated from a country which has a highly flexible exchange rate, unlike most of the previous crises which originated from some emerging economies with sticky exchange rate regimes. Another aspect is the slowness of its spread to parts of the financial and real sectors (See Willett et al., [6]). Despite the fact that the financial crisis started slowly at its inception, its problems had become increasingly evident through its devastating effects on other advanced economies especially Europe, Emerging Markets and Low Income Countries (LICs) and consequently led to a huge global downturn (Townsend, [7]).

The global financial crisis affected advanced economies and emerging markets and later LICs in different stages $^{2}$ (Figure 1). The first stage of the spread was characterized by the rapid spread of the financial turmoil from the United States to other developed economies and some Emerging Markets. Worth noting is that the effects of the financial crisis on Emerging Markets and LICs came later than for Europe and came largely through the trade effects of the recessions in the advanced economies. The Emerging Markets with well-developed financial systems were to a relatively lesser extent affected through cross border financial linkages especially capital flows and stock market investors that had spread the crisis quickly to Europe.

However, the case was different for many of the LICs where the effects of the crisis lagged behind the rest of the world. Comparing the effects of the crisis to the regions, one may note that the advanced economies suffered the most declines in real GDP followed by Emerging economies while SSA suffered the least declines in the real GDP on the average. Emerging economies recovery seems to be fastest (see Figure 1).

Expansionary fiscal policy was advocated by the IMF for countries that were faced with recession (IMF, [8]). However ability to use such policy is reduced by the fact that most developing countries could not afford to stimulate their economies through fiscal policy because of concerns about policy credibility and debt sustainability (Freedman et al., [9]; Kandil and Morsy, [10]).

Financing the resulting balance of payments deficits requires adequate reserves (Blinder, [11]). It is evident that, giving their inadequate reserves coupled with limited scope for countercyclical policies can make the effects of the financial crisis on the LICs large and persistent ${ }^{3}$. For the period 2008-2010, most of the LICs endowed with abundant reserves were oil producing countries, and countries such as Brazil and China. These countries had accumulated reserves which acted as a cushion during the crisis and simultaneously made them have better post crisis GDP growth (Dominguez et al., [12]).

A typical example of the effects on LICs is portrayed by the Sub-Sahara African region (except South Africa), which was less affected by the first round of the financial crisis effects mainly because of having weak financial

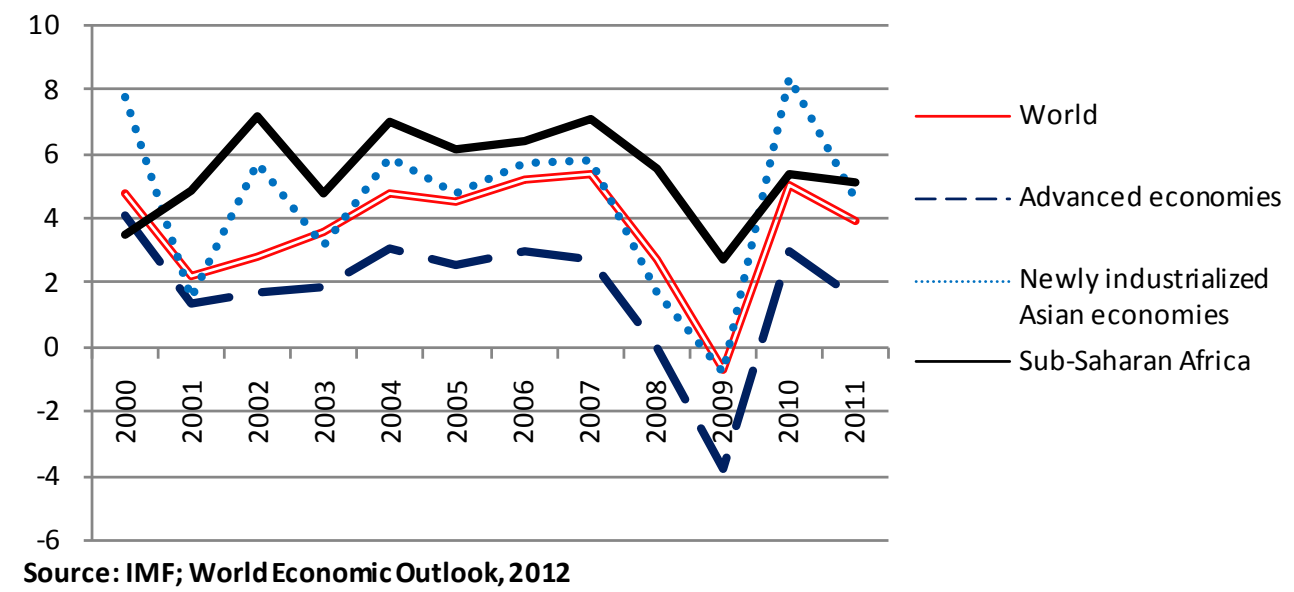

Figure 1. Economic growth by regions (\%).

\footnotetext{
${ }^{1}$ Particularly, as noted by Willett et al. [5], an important thing to note is that a continued increasing vulnerability for markets in advanced economies are considered to a large extent to be an important factor leading to the crisis, not the US subprime market alone.

${ }^{2}$ The data for this figure are annual because monthly data were not available for all regions.

${ }^{3}$ This however, does not imply that the LICs will never recover as there are already some optimistic indicators that these economies' performances are going back to the track. This follows the rising commodity demand and prices as a result of early recovery by some emerging economies especially India and China prices (UN-ECA, [17]).
} 
system coupled with low connection to the international financial system and less trade with advanced economies (IBRD, [13]).

\subsection{Significance of the Study}

There have been a number of qualitative studies to analyze the transmission mechanisms of the global financial crisis with respect to Tanzania (See BoT, [14]; ESRF, [15] and Ngowi, [16]). This study will examine the transmission channels of the global financial crisis to Tanzania using quantitative methods. It will contribute to the existing literature by providing a theoretical framework for understanding the significance of the channels for the transmission to a typical developing country such as Tanzania.

Against this background the channels to be examined are foreign aid, export earnings and Foreign Direct Investment (FDI $)^{4}$. I will also check the effectiveness of government expenditure to counter recession. The hypotheses to be tested are whether there exists a positive relationship between real GDP and each of the explanatory variables.

\subsection{Objectives of the Study}

I will examine the channels through which the ongoing financial crisis is affecting Tanzania. The key questions this empirical analysis seeks to answer are specific questions such as: How has the current financial crisis been transmitted to the Tanzanian economy? How strong are the transmission channels? What is the appropriateness of government policy responses to counter the recession?

\subsection{Data Sources}

Information on variables was collected from various sources including the Bank of Tanzania Economic and Operations Report (various), World Bank's Development Indicators, Ministry of Finance, IMF's website, National Accounts published by the National Bureau of Statistics and other official documents published by the government. The period to be covered is between 1970 and 2010 because of lack of time series statistical data for most of the earlier years and the lack of quarterly data.

\subsection{Financial System Stability for Tanzania}

The financial sector in Tanzania has embarked on a number of structural changes in a bid to enhance competitiveness since 2003. The changes provided an impetus for increasing the financial assets and this in turn led to expansion of the private sector credit and improving the financial intermediation hence contributing to growth of the economy. The key reform which was important for these developments was the Second Generation Financial Sector Reforms.

In order to ensure a stable financial sector, the government has enhanced surveillance through the Bank of Tanzania. The establishment of a mathematical model by which frequent "stress tests" are conducted is believed to be a reliable tool for surveillance to determine any sign of weakness and the Bank of Tanzania has also established intensified oversight of the banking system (BoT, [18]).

As noted in some studies on the current global financial crisis, many of the standard risk models had serious problems because they worked well during the normal times but couldn't give warning signals before the actualcrisis ${ }^{5}$. The stress test results for Tanzania have a weakness in data and this exposes the country to some risks because they may offer a false sense of security and facilitate the generation of excessive risk in the financial system. Therefore this calls for caution in interpretation of the results. There is a problem in obtaining detailed data for some smaller banks. In a recent vulnerability assessment the data problems led to "forcing exclusion of the smaller banks from some stress tests. Individual bank data that was available suffered from inconsistencies and unexplained outliers affecting the results" (IMF [19]).

\section{Literature Review}

One of the key cornerstones of financial crisis models is the Krugman's [20] seminal work, which attempts to

${ }^{4} \mathrm{I}$ do not include remittances because of its insignificance to the country's real GDP. Each of the variables is expressed as a ratio of real GDP.

${ }^{5}$ See Willett, [5]. 
explain how macroeconomic imbalances can lead to a collapse of the currency peg in an economy ${ }^{6}$. Krugman's article assumed that an exogenous fiscal deficit lay at the root of the balance of payments crisis and that the domestic economy uses monetary expansion to offset the fiscal deficit, causing a gradual reduction of foreign reserves. Eventually, the reserves are exhausted in a perfectly foreseen speculative attack leading to a collapse of the fixed exchange rate as the monetary authorities decide to abandon the fixed exchange rate system and the currency depreciates gradually overtime.

There were a number of other multi country studies on the aspect of speculations of the currency crisis such as Kaminski [21]. These multi-country studies produced a common result that they generally found evidence suggesting that weak fundamentals may lead to the propagation of currency crises. The common characteristic among most of these multi-country studies is that they use non-structural models and find mostly general results, but some of them have one major weakness, that they are not as statistically robust.

There are also several studies on contagion and the transmission channels. According to the literature, there is no single accepted definition of contagion (Willett et al., [5]). Among the mostly used definition is by Eichengreen [22] which states that contagion exists if "a crisis elsewhere in the world increases the likelihood of a particular country experiencing a crisis of its own, even after one controls for other observable fundamentals associated with crisis risk". There exist other types of contagion such as rational financial contagion, wakeup call contagion and contagion from market imperfections.

Masson [25] indicates how a crisis could spread from one economy to others through multiple equilibria mechanism. If there is a crisis happening in one country, then it tends to increase the probability of occurrence of a crisis in another country especially through trade. Investors tend to operate in several countries. If it happens that there is a crisis in one country, then the investors may reassess their positions in other countries. Incidentally the investors can lead to shifts in the market sentiments or changes in the interpretation given to existing information. This is what Masson [25] calls a specific type of contagion that cannot be explained with changes in the macroeconomic fundamentals.

Gamo et al. [26] in their IMF paper analyze the possible implications of the crisis on low income nations in a comprehensive examination. The authors examine impacts of the global financial crisis for a group of 71 Low Income Countries (LICs); these comprised the PRGF-eligible countries in Sub-Saharan Africa, Middle East, Asia, Latin America and Europe. The paper mentions key transmission mechanisms of the crisis such as trade, remittances, foreign direct investment, aid flow and fiscal and debt sustainability. The study found support that trade is indeed an important channel for contagion empirically. Most importantly, the authors help to demonstrate that trade links may explain the intensity as well as the incidence of currency crises as captured by measures of exchange rate pressure. Moreover, it is shown in the paper that the trade structure of exports for LICs remains highly concentrated on commodities.

In sum, the discussed theoretical framework implies that weak fundamentals and initial macroeconomic condition that may occur in an economy may not always be the only determinant to lead into the occurrence of the financial crisis. It is a combination of other factors like investor perception, contagion and the role of transmission channels that can lead to shift of the crisis elsewhere.

\section{Methodology}

In this section, I discuss the study that is pure methodology and the others which are applications from the developed methodology. This paper applies the Dynamic Ordinary Least Squares (DOLS) formulation which was proposed by Kao and Chiang [27].

The DOLS formulation was first proposed by Kao and Chiang [27] who examined the asymptotic distributions for Ordinary Least Squares (OLS), Fully Modified OLS (FMOLS), and Dynamic OLS (DOLS) estimators ${ }^{7}$. The authors employed their analysis based on the cointegrated regression models for homogenous and heterogenous panels. The study aimed at illustrating the finite sample properties of the OLS, FMOLS, and DOLS estimators, by conducting Monte Carlo experiments based on a formulation as follows:

$$
y_{i t}=\propto_{i}+\beta x_{i t}+u_{i t}
$$

where $\left\{y_{i t}\right\}$ are $1 \times 1$ dependent variables; $\beta$ is a $\mathrm{k} \times 1$ vector of slope parameters. Furthermore $\left\{\propto_{i}\right\}$, ${ }^{6}$ It is considered a cornerstone because many authors built on the Krugman's work through extensions and modifications. Most notable example was Flood and Garber [23] who introduced uncertainty and Obstfeld [24].

${ }^{7}$ Macias and Massa [27] is among the many authors who used the DOLS, first suggested by Kao and Chiang [28]. 
represents the intercepts and $u_{i t}$ are the stationary disturbance terms.

It is assumed that $\left\{x_{i t}\right\}$ are $\mathrm{k} \times 1$ integrated processes of order one, for all $i$, specified as follows:

$$
x_{i t}=x_{i t-1}+\varepsilon_{i t}
$$

where $i=1, \cdots, \mathrm{N}, t=1, \cdots, \mathrm{T}$. after performing some simulations, the authors came out with the following results:

$$
\left(\begin{array}{l}
u_{i t} \\
\varepsilon_{i t}
\end{array}\right)=\left(\begin{array}{l}
u_{i t}^{*} \\
\varepsilon_{i t}^{*}
\end{array}\right)+\left[\begin{array}{cc}
0.3 & -0.4 \\
\theta_{21} & 0.6
\end{array}\right]\left(\begin{array}{c}
u_{i t-1}^{*} \\
\varepsilon_{i t-1}^{*}
\end{array}\right)
$$

with

$$
\left(\begin{array}{c}
u_{i t}^{*} \\
\varepsilon_{i t}^{*}
\end{array}\right) \underline{i i d N}\left\{\left(\begin{array}{l}
0 \\
0
\end{array}\right),\left(\begin{array}{rr}
1 & \sigma_{21} \\
\sigma_{21} & 1
\end{array}\right)\right\}
$$

$\propto_{i}$ above was generated from a uniform distribution, $\mathrm{u}[0,10]$ and the authors decided to set $\beta=2$ for simplicity. It is postulated that the asymptotic results depend upon variances and covariances of the errors $u_{i t}$ and $\varepsilon_{i t}$. The authors show that the design in the above equation is proper because the endogeneity of the system is controlled by only two parameters above, $\theta_{21}$ and $\sigma_{21}$.

Analyzing the estimators for the OLS, FMOLS and DOLS; the authors demonstrated that all estimators were found to be asymptotically normally distributed. It was found that the asymptotic distribution of the OLS estimator has a non-zero mean. Finally, DOLS model was found to outperform both the OLS and FMOLS estimators for both the homogeneous and heterogeneous panels hence the DOLS estimator may be more promising than the OLS or FMOLS.

Hanh [29] applied the panel co-integration technique in order to examine the long-run relationship between economic growth, exports and foreign direct investment (FDI) inflows and estimates the VAR model. A sample of some Asian developing countries was used in the study which covered the period 1995-2008. The conclusion of the study was that the global financial crisis had a significant effect on developing Asia's growth through two main transmission channels namely FDI and exports.

The author found bidirectional causality between exports and FDI inflows for the developing Asian countries. The implication is that these countries were successful in implementation of the policy of export oriented development strategy, hence allowing foreign investment to expand the export sector. Similarly, the FDI flowed into these countries to take advantage of the fast growth in the exports sector.

I will apply the DOLS Model, expressed as follows:

$$
\begin{aligned}
G D P_{t}= & \propto_{0}+\propto_{1} A I D_{t}+\propto_{2} E X P R T_{t}+\propto_{3} F D I_{t}+\propto_{4} G O V_{t}+\sum_{S=-P}^{P} \beta_{S} \Delta A I D_{t-s} \\
& +\sum_{S=-P}^{P} \varnothing_{S} \Delta E X P R T_{t-s}+\sum_{S=-P}^{P} \gamma_{S} \Delta F D I_{t-s}+\sum_{S=-P}^{P} \vartheta_{S} \Delta G O V_{t-s}+\varepsilon_{t}
\end{aligned}
$$

where: GDP stands for real GDP growth rate, AID is foreign aid as percentage of real GDP; EXPRT represents exports as percentage of real GDP, FDI represents Foreign Direct Investment as percentage of real GDP and GOV is total government expenditure as percentage of real GDP with $\propto_{t}$ being the error term. The above equation is an extended version of DOLS with eventual lags and leads obtained by using information criterion.

\section{Regression Results and Comparison to Other Studies}

Finally, I turn to the Dynamic Ordinary Least Squares (DOLS) model. I apply the variables which I anticipate could be the possible transmission channels and use the lags and leads based on the information criteria. The desirable model was the one which has two lags and two leads (See Table 1(a), Appendices). In Table 1, I present the coefficients of the model, which are shown to be statistically significant at 5 percent level ${ }^{8}$.

The results show that FDI positively affects growth and remains statistically significant at 5 percent level. From the table above, a drop in FDI of one percent of GDP could lead to lower economic growth by 0.05

${ }^{8}$ I present here the regression summary which contains the few variables whereas the full model with the lags is attached in the appendix Table 1(a). 
Table 1. Dynamic OLS estimates.

\begin{tabular}{ccccc}
\hline Variable & Coefficient & Std. Error & t-Statistic & Prob. \\
FDI & 0.053236 & 0.017426 & 3.054975 & 0.0447 \\
GOV & -0.019251 & 0.003256 & -5.912470 & 0.0157 \\
AID & 0.151072 & 0.029037 & 5.202741 & 0.0225 \\
EXPORTS & 0.130681 & 0.025669 & 5.091005 & 0.0328 \\
D_FDI(-1) & 1.145415 & 0.458919 & 2.495901 & 0.0412 \\
D_GOV(-1) & 0.298499 & 0.257358 & 1.159860 & 0.2841 \\
R-squared & 0.838257 & Mean dependent var & 4.122682 \\
Adjusted R-squared & 0.803212 & S.D. dependent var & 2.556534 \\
S.E. of regression & 1.134099 & Akaike info criterion & 3.097340 \\
Sum squared resid & 9.003271 & Schwarz criterion & 4.309450 \\
Log likelihood & -25.65478 & Hannan-Quinn criter. & 3.510704 \\
F-statistic & 6.180499 & Durbin-Watson stat & 2.818893 \\
Prob(F-statistic) & 0.009353 & & \\
\hline
\end{tabular}

percentage points. Although this magnitude is fairly small it is statistically significant. It is widely acknowledged that the FDI plays an important role to economic performance of the recipient particularly developing countries.

The results are in line with the common notion that the FDI is regarded as the "engine of growth" in developing countries. FDI is important especially in the short run whereby its increase will lead to increases in capital stock (higher investment) and stimulates consumption hence leading to economic growth when there is efficient use of the existing resources especially technology. Furthermore, endogenous models highlight the idea of enhancement in technology, efficiency, and productivity and also suggest that FDI can positively influence the growth rate provided that it is associated with increasing returns in production via externalities and production spillovers (Barro and Sala-i-Martin, [30]). The similar results were also found for studies covering Sub-Saharan Africa (Macias and Massa, [27]).

I found that the effects of government expenditure as a percentage of GDP on rate of economic growth are contrary to how I expected. The use of expansionary fiscal policy or what is popularly known as the stimulus package can lead to negative effects in the Tanzanian economy. The results show that an increase in government expenditure by 10 percentage points lead to a decrease of growth of the real GDP by 0.1 percentage points and is statistically significant at 5 percent level.

Generally, from the point of view of the theory, an increase of government expenditure in the form of public investment can lead to contraction of private investment or in other words crowding out process. Similar results were obtained in (Ilzetzki et al., [31]) with respect to developing countries and Sub-Saharan Africa countries. Most of the countries in this region face a limitation in how they can use fiscal policy to create the stimulus plans in a sustainable manner. I therefore support the supposition by (Kandil and Morsy, [10]; Freedman et al., [9]) that although fiscal expansion can be important to speed up recovery, some countries do not have sufficient resources to sustainably finance it.

A study by Gupta et al. [32] explains the conditions for fiscal stimuli to increase economic growth in a typical low income country. The authors analyzed the expenditure composition and fiscal adjustment in a group of 39 low income countries. The results show that strong budgetary positions and fiscal consolidation are associated with higher economic growth in the short and long run. The authors further show that the compositions of the expenditure outlays matters i.e. on the average the countries where spending is concentrated on wages and transfers tend have lower economic growth. On the contrary, the countries which spend a larger proportion on capital and nonwage goods will have a higher and faster economic growth ${ }^{9}$.

In sum, the foregoing studies show that the obtained results do not sound uncommon. I also acknowledge that

\footnotetext{
${ }^{9}$ The Tanzania's 5 year development plan which spans from 2011/12 to 2015/16, is the formal implementation tool of the country's development agenda, articulated in the Tanzania Development Vision 2025. The plan states that the recurrent expenditure (of which wages and salaries is a big proportion, exceeding 50 percent) has been growing fast compared to the development expenditure resulting into a huge burden to taxpayers. The Plan lays out ways of reducing this tendency.
} 
initial and accompanying macroeconomic and fiscal conditions are important. Finally referring to the results; obtaining a negative elasticity may seem to be not plausible to many. I obtained a -0.01 coefficient which is not substantially different from zero. Although the result is statistical significance, this fact may not always imply economic significance.

Foreign aid bears the positive sign as was expected and is statistically significant this implies a possibility that the ongoing global crisis could have impacted the economy of Tanzania through a reduced in foreign aid which is associated with recession in the developed economies which are aid donors. I support these results from theoretical standpoint that foreign aid is important as it provides the required capital to help close the dual gap. I interpret the results in the context of the crisis that a drop in foreign aid of one percent of GDP could lead to lower economic growth by 0.15 percentage points. Ndambendia et al. [33] is one of the studies done in the Sub Sahara African region that had similar findings. In the study, the authors had investigated a long-run relationship between foreign aid, foreign direct investment and economic growth in 36 Sub-Saharan Africa countries over the period 1980-2007. They found an evidence of positive impact of foreign aid and foreign direct investment on economic growth.

Exports have the desired sign and are statistically significant. An increase of exports of goods and services by 10 percent will lead to increase of growth rate of the GDP by 1.3 percentage points. This result confirms that of previous studies such as Gamo et al. [26].

\section{Conclusion}

This study found that foreign aid is relatively the most important transmission channel for the global financial crisis, followed by export earnings. The country will need to continue enhancing the bilateral and multilateral strategy of building in mechanisms towards self-dependence as stipulated in the country's development vision. Policies aimed at improving earnings from exports may play an important role for the country's sustained economic growth initiatives. Overall, the global financial crisis had only a small impact in Tanzania's economy.

\section{References}

[1] IMF (2009) Regional Economic Outlook: Sub-Saharan Africa. International Monetary Fund (IMF), Washington DC.

[2] IMF (2009) Regional Economic Outlook: Sub-Saharan Africa-Weathering the Storm. World Economic and Financial Surveys, International Monetary Fund (IMF), Washington DC.

[3] AfDB (2010) Africa in the Wake of the Global Financial Crisis: Challenges Ahead and the Role of the Bank. Policy Briefs on the Financial Crisis, No. 1, African Development Bank, Abidjan.

[4] Wakeman-Linn, J., Portillo, R., Iossifov, P. and Milkov, D. (2009) The International Financial Crisis and Global Recession: Impact on the CEMAC Region and Policy Considerations. IMF Staff Position Note, No SPN/09/20, International Monetary Fund (IMF), Washington DC.

[5] Willett, T. (2009) The Role of Defective Mental Models in Generating the Current Financial Crisis. A paper Prepared for the Cornell Workshop on the Global Implications of the Financial Crisis. Journal of Financial Economic Policy (forthcoming).

[6] Willett, T., Liang, P. and Zhang, N. (2010) The Slow Spread of the Global Financial Crisis. Journal of International Commerce, Economics, and Policy, 1, 33-58; presented at the Annual Meetings of the APEA in Santa Cruz, June 2010 and of the WEA in Vancouver, July 2010.

[7] Townsend, I. (2009) Global Economic Crisis and Developing Countries. Economic Policy and Statistics Section.

[8] International Monetary Fund (2009) Coping with the Crisis: Policy Options for Emerging Market Economies, Research Department.

[9] Freedman, C., Kumhof, M., Laxton, D. and Lee, J. (2009) The Case for Global Fiscal Stimulus. IMF Staff Position Note 09/01, International Monetary Fund, Washington DC.

[10] Kandil, M. and Morsy, H. (2010) Fiscal Stimulus and Credibility in Emerging Countries. IMF Country Report No. 10/177, International Monetary Fund, Washington DC.

[11] Blinder, A.S. (2004) The Case against Discretionary Fiscal Policy. CEPS Working Paper, No. 100.

[12] Dominguez, K.M. (1992) Intramarginal Intervention in the EMS and the Target-Zone Model of Exchange-Rate Behavior. European Economic Review, 36, 1523-1532. http://dx.doi.org/10.1016/0014-2921(92)90003-F

[13] IBDR (2008) Global Financial Crisis and Implications for Developing Countries. G-20 Finance Ministers’ Meeting, 
Sao Paulo, 8 November 2008, 9p.

[14] Bank of Tanzania (2009) Monthly Economic Review, October, Dar es Salaam.

[15] Economic and Social Research Foundation ESRF (2009) The Global Financial Crisis and Tanzania: Effects and Policy Responses. Report published in collaboration with the Overseas Development Institute (ODI).

[16] Ngowi, Honest (2010) The Current Global Economic Crisis and Its Impacts in Tanzania. African Journal of Business Management, 4, 1468-1474.

[17] UNECA and OECD (2009) The Mutual Review of Development Effectiveness in Africa: Promise and Performance, Joint UNECA and OECD Report.

[18] Bank of Tanzania (2011) Monthly Economic Review, September. Bank of Tanzania, Dar es Salaam.

[19] International Monetary Fund (2010) United Republic of Tanzania: Financial System Stability Assessment Update. June 2010. IMF Country Report No. 10/177.

[20] Krugman, P. (1979) A Model of Balance of Payments Crises. Journal of Money, Credit and Banking, 11, 311-325. http://dx.doi.org/10.2307/1991793

[21] Kaminsky, G.L. and Reinhart, C.M. (1999) The Twin Crises: The Causes of Banking and Balance of Payments Problems. American Economic Review, 89, 473-500. http://dx.doi.org/10.1257/aer.89.3.473

[22] Eichengreen, Barry (2003) Crisis and Inflows. The MIT Press Cambridge, Massachusetts London, England.

[23] Flood, R. and Garber, P. (1984) Collapsing Exchange rate Regimes: Some Linear Examples. Journal of International Economics, 17, 1-13. http://dx.doi.org/10.3386/w5318

[24] Obstfeld (1986) Rational Self-Fulfilling Balance of Payments Crises. American Economic Review, 76, 72-81.

[25] Masson, P. (1998) Contagion Effect: Monsoonal Effects, Spillovers, and Jump between Multiple Equilibria. IMF Working Paper No. 142, International Monetary Fund, Washington DC.

[26] Gamo, P.A., Das, U. and Helbling, T. (2009) The Implications of the Global Financial Crisis for Low-Income Countries. International Monetary Fund, Washington DC.

[27] Macias, B.J. and Massa, I. (2009) The Global Financial Crisis and Sub-Saharan Africa: The Effects of Slowing Private Capital Inflows on Growth. Working Paper 304, Overseas Development Institute (ODI), London.

[28] Kao, C. and Chiang, M.-H. (2000) On the Estimation and Inference of Cointegrated Regression in Panel Data. In: Baltagi, B.H., Ed., Advanced Econometrics: Non Stationary Panels, Panel Cointegration and Dynamic Panels, Vol. 15, Emerald Group Publishing Limited, Bingley, 179-222.

[29] Hahn, H. and Thi, P. (2009) Effects of the 2008 Financial Crisis on Developing Asia’s Economic Growth. Economics Bulletin, 30, 1922-1934.

[30] Barro, R. and Sala-i-Martin, X. (1997) Technology Diffusion, Convergence, and Growth. Journal of Economic Growth, 2, 1-26. http://dx.doi.org/10.1023/A:1009746629269

[31] Ilztetzki, E. and Vegh, C.A. (2008) Procyclical Fiscal Policy in Developing Countries: Truth or Fiction? NBER Working Paper No. W14191, National Bureau of Economic Research, Cambridge.

[32] Gupta, S., Clemence, B., Baldacci, E. and Munos-Granados, C. (2005) Fiscal, Policy, Expenditure Composition and Growth in Low Income Countries. Journal of International Money and Finance, 24, 441-463.

[33] Ndambedia, H. (2011) Foreign Aid, Direct Investment and Economic Growth in Sub Saharan Africa: Evidence from Pooled Mean Group Estimator (PMG). International Journal of Economics and Finance, 2, 39-45. 


\section{Appendices}

Table 1(a). Dynamic ordinary least squares model (DOLS).

\begin{tabular}{|c|c|c|c|c|}
\hline $\begin{array}{l}\text { Dependent Variable: GDP } \\
\text { Method: Least Squares }\end{array}$ & & & & \\
\hline Variable & Coefficient & Std. Error & t-Statistic & Prob. \\
\hline FDI & 0.053236 & 0.017426 & 3.054975 & 0.0447 \\
\hline GOV & -0.019251 & 0.003256 & -5.912470 & 0.0157 \\
\hline AID & 0.151072 & 0.029037 & 5.202741 & 0.0225 \\
\hline EXPORTS & 0.130681 & 0.025669 & 5.091005 & 0.0328 \\
\hline D_FDI $(-1)$ & 1.145415 & 0.458919 & 2.495901 & 0.0412 \\
\hline D_GOV(-1) & 0.298499 & 0.257358 & 1.159860 & 0.2841 \\
\hline D_EXPORTS(-1) & 0.124392 & 0.266928 & 0.466014 & 0.6554 \\
\hline D_AID $(-1)$ & 6.557645 & 1.630833 & 4.021041 & 0.0051 \\
\hline D_FDI(1) & 1.103174 & 0.238262 & 4.630089 & 0.0024 \\
\hline D_GOV(1) & -0.167113 & 0.149642 & -1.116751 & 0.3010 \\
\hline D_EXPORTS(1) & 0.632900 & 0.335216 & 1.888035 & 0.1010 \\
\hline D_AID(1) & 0.185465 & 1.649278 & 0.112452 & 0.9136 \\
\hline D_FDI & 1.395902 & 0.532126 & 2.623254 & 0.0342 \\
\hline D_EXPORTS & 0.358355 & 0.319400 & 1.121962 & 0.2989 \\
\hline D_AID & 9.683080 & 1.650450 & 5.866933 & 0.0006 \\
\hline D_GOV & 0.577394 & 0.377568 & 1.529243 & 0.1701 \\
\hline D_GOV(-2) & 0.111458 & 0.172318 & 0.646813 & 0.5384 \\
\hline D_EXPORTS(-2) & 0.428819 & 0.204666 & 2.095210 & 0.0744 \\
\hline D_AID $(-2)$ & 2.873678 & 1.406747 & 2.042782 & 0.0804 \\
\hline D_FDI $(-2)$ & 0.530181 & 0.334881 & 1.583191 & 0.1574 \\
\hline D_GOV(2) & 0.085538 & 0.131128 & 0.652325 & 0.5350 \\
\hline D_EXPORTS(2) & 0.219730 & 0.233925 & 0.939319 & 0.3788 \\
\hline D_AID(2) & 3.196480 & 1.915755 & 1.668522 & 0.1391 \\
\hline D_FDI(2) & -0.556570 & 0.166286 & -3.347064 & 0.0123 \\
\hline C & 64.16654 & 12.53538 & 5.118833 & 0.0014 \\
\hline R-squared & 0.838257 & \multicolumn{2}{|c|}{ Mean dependent var } & 4.122682 \\
\hline Adjusted R-squared & 0.803212 & \multicolumn{2}{|c|}{ S.D. dependent var } & 2.556534 \\
\hline S.E. of regression & 1.134099 & \multicolumn{2}{|c|}{ Akaike info criterion } & 3.097340 \\
\hline Sum squared resid & 9.003271 & \multicolumn{2}{|c|}{ Schwarz criterion } & 4.309450 \\
\hline Log likelihood & -25.65478 & \multicolumn{2}{|c|}{ Hannan-Quinn criter. } & 3.510704 \\
\hline F-statistic & 6.180499 & \multicolumn{2}{|c|}{ Durbin-Watson stat } & 2.818893 \\
\hline Prob (F-statistic) & 0.009353 & & & \\
\hline
\end{tabular}

